\title{
Urinary Prostaglandins and the Effect of Indomethacin on Phosphate Excretion in Children With Hypophosphatemic Rickets
}

\author{
MOUIN G. SEIKALY, PAMELA G. WABER, AND MICHEL BAUM
}

\begin{abstract}
Department of Pediatrics [M.G.S., P.G.W., M.B.], Department of Internal Medicine [M.B.], University of Texas Southwestern Medical
\end{abstract} Center, Dallas, Texas 75390; Texas Scottish Rite Hospital for Children [M.G.S.], Dallas, Texas 75390

\begin{abstract}
We recently reported the urinary prostaglandin $\mathrm{E}_{2} /$ creatinine ratio $\left(\mathrm{PGE}_{2} / \mathrm{Cr}\right)$ was markedly elevated in Hyp mice, the animal model for X-linked hypophosphatemia, compared with control mice. We provided evidence for altered prostaglandin production mediating the phosphaturia and that indomethacin decreases urinary phosphate excretion in Hyp mice but not control mice. To determine the levels of urinary $\mathrm{PGE}_{2} / \mathrm{Cr}$, the safety and efficacy of indomethacin on phosphate excretion in children with hypophosphatemic rickets (HPR), a prospective clinical trial was performed in 16 children with HPR and 16 age- and gender-matched healthy controls. Urinary $\mathrm{PGE}_{2} / \mathrm{Cr}$ excretion was determined on a $24 \mathrm{~h}$ timed urine collection. A randomized cross over, placebo versus indomethacin, clinical trial was performed in the 16 children with HPR. There was no difference in urinary $\mathrm{PGE}_{2} / \mathrm{Cr}$ excretion between controls and patients with HPR. In children with HPR, indomethacin treatment for 3 mo had no significant effect on serum phosphorus or urinary phosphate excretion. In conclusion, urinary prostaglandin excretion is similar in children with HPR compared with controls. Indomethacin had no significant effect on serum phosphorus or urinary phosphate excretion in children with HPR. (Pediatr Res 64: 210-212, 2008)
\end{abstract}

$\mathrm{H}$ ypophosphatemic rickets (HPR) is characterized by hypophosphatemia because of impaired proximal tubular reabsorption of phosphate. HPR is associated with X-linked hypophosphatemia (XLH), autosomal dominant hypophosphatemic rickets, oncogenic rickets, and Fanconi's syndrome. $\mathrm{XLH}$ is the most common inherited defect in tubular phosphate transport. The resulting hypophosphatemia leads to defective bone mineralization (1). XLH is secondary to a mutation in a phosphate-regulating gene with endopeptidase activity located on the $X$ chromosome (2). Most patients with XLH have elevated serum fibroblast growth factor-23 (FGF23) levels (3), as do patients with tumor induced osteomalacia and autosomal dominant hypophosphatemic rickets $(4,5)$. We have recently shown that Hyp mice have elevated urinary prostaglandin $\mathrm{E}_{2} /$ creatinine levels $\left(\mathrm{PGE}_{2} / \mathrm{Cr}\right)$ compared with controls (6) and that administration of FGF-23 to control mice increases urinary $\mathrm{PGE}_{2} / \mathrm{Cr}$ excretion and renal tubular production of $\mathrm{PGE}_{2}$ (7). In addition, administration of indomethacin to Hyp mice results in an increase in proximal tubule phos-

Received November 16, 2007; accepted March 5, 2008

Correspondence: Mouin G. Seikaly, M.D., University of Texas Southwestern Medical Center of Dallas, 5323 Harry Hines Blvd., Dallas, Texas 75390-9063; e-mail: mouin.seiklay@utsouthwestern.edu

This study was funded by an Institutional Grant from the Texas Scottish Rite Hospital for Children, Dallas, Texas (03-04-656 to M.S) and NIH (5R01- DK065842 to M. B.). phate transport, a reduction in fractional excretion of phosphate and an increase in serum phosphorus levels (6). The aim of the present study was to determine urinary $\mathrm{PGE}_{2} / \mathrm{Cr}$ excretion levels in patients with HPR compared with controls and whether treatment with indomethacin for 3 mo will decrease phosphate excretion in children with HPR.

\section{MATERIALS AND METHODS}

We prospectively measured urinary $\mathrm{PGE}_{2} / \mathrm{Cr}$ in $24-\mathrm{h}$ urine collections in seven male and nine female children with HPR and 16 age and sex matched controls. Fifteen of the patients with HPR had a family history consistent with an X-linked mode of inheritance. The diagnosis of HPR was established by the clinical and biochemical criteria we have described previously (8). The average age of the patients with XLH was $11.8 \pm 0.9$ y (range 5-17 y). Sixteen healthy volunteer children were recruited to serve as controls $12.1 \pm$ 1.0 y (range $5-18 \mathrm{y}$ ).

We also performed a prospective double-blind crossover study using indomethacin (Qualitest Pharmaceuticals, Inc., Huntsville, Alabama) as the treatment drug and a placebo as control drug in the above children with HPR. The dose of indomethacin was $2 \mathrm{mg} / \mathrm{kg} / \mathrm{d}$ rounded to the next higher multiple of $25 \mathrm{mg}$ (maximum $150 \mathrm{mg} / \mathrm{d}$ ). The indomethacin was administered three times daily. The indomethacin dose once determined was not altered during the study. Indomethacin was pulverized and placed in $25 \mathrm{mg}$ capsules to match placebo capsules; the latter were compounded using sodium bicarbonate fillers (Pharmacy Compounding Specialties, Dallas, Texas). Patients were randomized to receive either placebo or drug for 3 mo then crossed over to receive either drug or placebo for additional 3 mo. Data from only 11 of the above patients who completed the 6-mo study were analyzed. Five patients exited the study because of either drug intolerance or they did not adhere to the study protocol. There were four males and seven females who completed the study. All patients who entered the drug study had XLH.

At the time of enrollment in the study, all patients with XLH were maintained on calcitriol (Rocaltrol, Hoffmann-LaRoche, Basel Switzerland) at $17.8 \pm 2.3 \mathrm{ng} / \mathrm{kg}$ body $\mathrm{wt} / \mathrm{d}$, and oral phosphate at $10.3 \pm 2.4 \mathrm{mg} / \mathrm{kg}$ body $\mathrm{wt} / \mathrm{d}$. Conventional therapy with calcitriol and oral phosphate was adjusted to maintain clinical remission of rickets, normal PTH levels, and a urinary calcium excretion of less than $1 \mathrm{mmol} / \mathrm{kg}$ body $\mathrm{wt} / \mathrm{d}$. The phosphate and calcitriol doses were not altered after initiation of the study. Four patients were treated with hydrochlorothiazide $(0.53 \pm 0.24 \mathrm{mg} / \mathrm{kg} / \mathrm{d})$ to control their hypercalcuria. Evaluation of study subjects with XLH included: a) physical exam; b) blood analysis for a creatinine, electrolytes, calcium, phosphorus, alkaline phosphatase, PTH, 1,25 $(\mathrm{OH})_{2}$ vitamin D, osteocalcin; c) timed urine for creatinine, calcium and $\mathrm{PGE}_{2}$ excretion. Tubular maximum of phosphate reabsorption (TmP/GFR) was computed using the formula: TmP/GFR $=S_{P}-\left[\frac{U_{P} \cdot S_{c r}}{U_{C r}}\right]$ as previously described, where $S_{P}$ and $S_{C r}$ are serum phosphorus and creatinine, respectively, and $\mathrm{U}_{\mathrm{P}}$ and $\mathrm{U}_{\mathrm{Cr}}$ are urine phosphate and creatinine, respectively (9). Control subjects had a $24 \mathrm{~h}$ timed urine collection for creatinine, calcium, and $\mathrm{PGE}_{2}$. Urinary $\mathrm{PGE}_{2}$ levels were measured by RIA (Core Endocrine Laboratories, Hershey, PA). All timed

Abbreviations: ADHR, autosomal dominant hypophosphatemic rickets; HPR, hypophosphatemic rickets; $\mathbf{P G E}_{2} / \mathbf{C r}$, prostaglandin divided by urine creatinine; TmP/GFR, tubular maximum for the reabsorption of phosphate; XLH, X-linked hypophosphatemia 
Table 1. Serum indices and urinary indices in children with XLH (prior to treatment with indomethacin) and age matched controls

\begin{tabular}{|c|c|c|c|c|}
\hline & Reference range & $\mathrm{XLH}(n=16)$ & Control $(n=16)$ & $p$ \\
\hline Serum phosphorus (mmol/L) & $0.80-1.60$ & $0.81 \pm 0.05$ & N/A & N/A \\
\hline Serum calcium $(\mathrm{mmol} / \mathrm{L})$ & $2.20-2.58$ & $2.21 \pm 0.02$ & N/A & N/A \\
\hline Serum osteocalcin (ng/mL) & $16.3-68.7$ & $87.81 \pm 9.42$ & N/A & N/A \\
\hline Alkaline phosphatase (IU/L) & Age dependent references (10) & $414.63 \pm 42.01$ & N/A & N/A \\
\hline Intact-PTH $(\mathrm{pmol} / \mathrm{L})$ & $9-78$ & $70.4 \pm 8.2$ & N/A & N/A \\
\hline Serum $1,25(\mathrm{OH})_{2}$ Vit D $(\mathrm{pg} / \mathrm{mL})$ & $27-71$ & $57.6 \pm 4.6$ & N/A & N/A \\
\hline \multicolumn{5}{|l|}{ Urine } \\
\hline TmP/GFR (mg/dL) & Age dependent references (9) & $1.95 \pm 0.13$ & N/A & N/A \\
\hline Urinary $\mathrm{Ca}(\mathrm{mmol} / \mathrm{kg} / \mathrm{d})$ & $<1.0$ & $0.36 \pm 0.08$ & N/A & N/A \\
\hline Urinary $\mathrm{PGE}_{2}(\mathrm{ng} / 24 \mathrm{~h})$ & Age dependent reference values & $379.4 \pm 83.3$ & $318.1 \pm 103.4$ & $p=0.163$ \\
\hline Urinary $\mathrm{PGE}_{2} / \mathrm{Cr}(\mathrm{ng} / \mathrm{mg})$ & - & $0.36 \pm 0.04$ & $0.32 \pm 0.07$ & $p=0.052$ \\
\hline
\end{tabular}

N/A, not available.

urine collections were refrigerated during collection period and transferred to clinic on ice. When received in the clinic, urine samples were frozen at $-20^{\circ} \mathrm{C}$ and shipped to the reference laboratory.

Data are reported as the mean \pm standard error o the mean. Paired two tailed $t$ test was used to evaluate the before and after periods. Urinary $\mathrm{PGE}_{2} / \mathrm{Cr}$ compared in controls and patients with HPR using the MannWhitney Rank Sum Test whereas urinary PGE $_{2}$ was compared in controls and patients with HPR using a two tailed unpaired $t$ test. Determination of whether there was a correlation between urinary $\mathrm{PGE}_{2} / \mathrm{Cr}$ and urine $\mathrm{TmP} / \mathrm{GFR}$ was made using linear regression. When placebo was given for the first $3 \mathrm{mo}$, we used data obtained at the 3-mo visit for baseline values. If indomethacin was given for the first $3 \mathrm{mo}$, we used data obtained at the baseline (or $0 \mathrm{mo}$ ) visit for baseline values. The study protocol was approved by the Institutional Review Board of the University of Texas Southwestern Medical Center. The legal guardian of every eligible patient and volunteer control consented to participation in this study.

\section{RESULTS}

Serum and urinary indices of children with XLH before treatment with indomethacin and their age-matched controls are shown in Table 1. All children with HPR were in clinical and radiologic remission of their rickets at the time of enrollment into the study. Serum alkaline phosphatase, osteocalcin, and PTH were within ranges normal for age (10). TmP/GFR was low while urinary calcium excretion was normal in all enrolled children with HPR. $\mathrm{PGE}_{2} / \mathrm{Cr}$ was $0.43 \pm 0.07 \mathrm{ng} / \mathrm{mg}$ compared with $0.31 \pm 0.03 \mathrm{ng} / \mathrm{mg}$, in male and female patients with HPR, respectively $(p=0.11)$. There was no difference in urinary $\mathrm{PGE}_{2} / \mathrm{Cr}$ excretion between controls $(0.32 \pm 0.07 \mathrm{ng} / \mathrm{mg})$ and patients with XLH $(0.36 \pm 0.04$ $\mathrm{ng} / \mathrm{mg})(p=0.052)$ (Fig. 1). There were two very high values for $\mathrm{PGE}_{2} / \mathrm{Cr}$ in the control group. The reason for the discordance from the other controls is not clear but they were not ill during the time of study. There was no correlation between urinary $\mathrm{PGE}_{2} / \mathrm{Cr}$ levels and TmP/GFR $(R=0.023, p>0.05)$.

The serum and urine biochemical data of patients with HPR before and after treatment with indomethacin are shown in Table 2. Treatment with indomethacin was well tolerated in the children with HPR. Indomethacin treatment for 3 mo decreased $\mathrm{PGE}_{2} / \mathrm{Cr}$ excretion $(0.34 \pm 0.11$ versus $0.26 \pm$ $0.14 \mathrm{ng} / \mathrm{mg}, p<0.05)$. However, indomethacin had no effect on serum phosphorus $(0.79 \pm 0.15$ versus $0.81 \pm$ $0.10 \mathrm{mM})$ or urinary phosphate excretion $(1.84 \pm 0.49$ versus $1.94 \pm 0.39 \mathrm{mg} / \mathrm{dL}$ ).

\section{DISCUSSION}

Current therapy for HPR includes oral vitamin D and phosphate. Although this therapy is effective in healing rickets

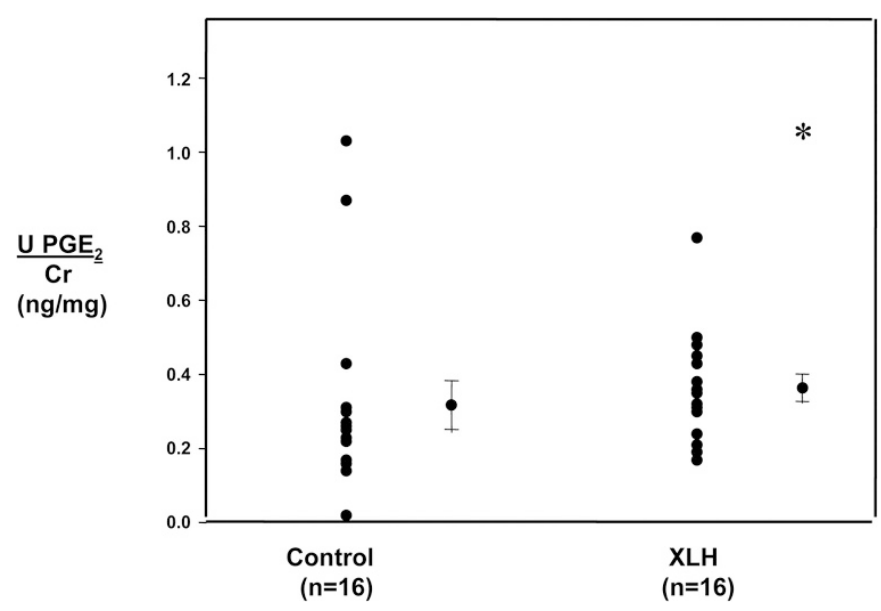

Figure 1. Urinary Prostaglandin excretion $\left(\mathrm{PGE}_{2} / \mathrm{Cr}\right)$ in controls and patients with XLH $(* p=0.052)$.

and decreasing bone pain, it does not significantly improve growth (8). In addition, this therapy is associated with morbidity including nephrocalcinosis and hyperparathyroidism $(11,12)$. Thus, finding a safer therapy would be of benefit to patients with HPR.

Our previous studies provided several lines of evidence that there is altered prostaglandin production in Hyp mice that is mediated by FGF-23 $(6,7)$. Urinary $\mathrm{PGE}_{2}$ excretion is about 2-fold greater in Hyp mice compared with control mice (6). Incubation of a tubule suspension enriched for proximal tubules had a higher rate of production of $\mathrm{PGE}_{2}$ in Hyp mouse tubules than that of control tubules (7). Injection of FGF-23 into C57/B6 mice resulted in an increase in urinary $\mathrm{PGE}_{2} / \mathrm{Cr}$ excretion compared with vehicle-treated mice and incubation of a control mouse tubule preparation with FGF-23 resulted in an increase in $\mathrm{PGE}_{2}$ production compared with vehicle (7). Finally, we demonstrated that $\mathrm{PGE}_{2}$ could inhibit phosphate transport in the perfused control mouse proximal tubule and incubation of control mouse proximal tubules with $\mathrm{PGE}_{2}$ results in a decrease brush border membrane vesicle $\mathrm{NaPi}-2 \mathrm{~A}$ expression (7).

The potential importance of the above findings was demonstrated by the effect of indomethacin treatment in Hyp mice (6). Hyp mice treated with indomethacin for $4 \mathrm{~d}$ had a decrease of their fractional excretion of phosphate, an increase in their serum phosphorus level, and an increase in proximal tubule 
Table 2. Effect of 3 mo of indomethacin on serum and urinary biochemical indices in children with XLH

\begin{tabular}{|c|c|c|c|c|}
\hline & Reference range (SI) & Baseline $(n=11)$ & Indomethacin $(n=11)$ & $p$ \\
\hline Indomethacin (mg/kg/d) & $2-3$ & $2.8 \pm 0.7$ & $2.7 \pm 0.8$ & NS \\
\hline Serum phosphorus (mmol/L) & $0.80-1.60$ & $0.79 \pm 0.15$ & $0.81 \pm 0.10$ & NS \\
\hline Serum calcium (mmol/L) & $2.20-2.28$ & $2.21 \pm 0.09$ & $2.21 \pm 0.12$ & NS \\
\hline Serum creatinine $(\mathrm{mmol} / \mathrm{L})$ & $50-110 \mu \mathrm{mol} / \mathrm{L}$ & $42 \pm 15$ & $45 \pm 15$ & NS \\
\hline Alkaline phosphatase (IU/L) & Age dependent references (18) & $419 \pm 171$ & $415 \pm 167$ & NS \\
\hline Serum intact-PTH $(\mathrm{pmol} / \mathrm{L})$ & $9-78$ & $83 \pm 35$ & $79 \pm 31$ & NS \\
\hline Serum osteocalcin (ng/mL) & $16.3-68.7$ & $99.3 \pm 29.7$ & $106.2 \pm 34.5$ & NS \\
\hline $1,25(\mathrm{OH})_{2}$ Vit $\mathrm{D}(\mathrm{pg} / \mathrm{mL})$ & $27-71$ & $60 \pm 20$ & $48 \pm 14$ & NS \\
\hline \multicolumn{5}{|l|}{ Urine } \\
\hline Urinary calcium $(\mathrm{mmol} / \mathrm{kg} / \mathrm{d})$ & $0.12-0.23$ gender dependent & $0.38 \pm 0.29$ & $0.30 \pm 0.30$ & NS \\
\hline $\mathrm{TmP} / \mathrm{GFR}(\mathrm{mg} / \mathrm{dL})$ & Age dependent references (9) & $1.84 \pm 0.49$ & $1.94 \pm 0.39$ & NS \\
\hline Urinary $\mathrm{PGE}_{2} / \mathrm{Cr}(\mathrm{ng} / \mathrm{mg})$ & & $0.34 \pm 0.11$ & $0.26 \pm 0.14$ & $p<0.05$ \\
\hline
\end{tabular}

brush border membrane vesicle $\mathrm{NaPi}-2 \mathrm{~A}$ protein expression compared with vehicle-treated mice. Control mice treated with indomethacin did not have a difference in any of these parameters. Thus, in Hyp mice, indomethacin may have potential benefit, but it was never determined if it improved their rickets with long-term therapy or if long-term therapy with indomethacin resulted in a chronic increase in serum phosphate levels.

Our current study showed that urinary $\mathrm{PGE}_{2} / \mathrm{Cr}$ was slightly higher than age- and gender-matched healthy control subjects. Although the difference neared statistical significance $(p=$ 0.052), there is a significant amount of overlap between the two groups. A lack of significance may be the result from the number of patients in these groups and the two-outlier controls. In addition, there are several shortcomings to the present study. Alterations in dietary sodium and potassium intake can affect urinary prostaglandin excretion (13). Thus, the fact that our patients were not on a controlled diet could have affected their urinary prostaglandin excretion. In addition, $\mathrm{PGE}_{2}$ is produced in many nephron segments and urinary $\mathrm{PGE}_{2}$ reflects the prostaglandin production of all sites of production (14-17). Thus, this study does not address if there is increased proximal tubule prostaglandin production in HPR as we have shown in Hyp mice. Although we found a significant reduction in urinary $\mathrm{PGE}_{2} / \mathrm{Cr}$ ratios in patients with XLH treated with indomethacin, the reduction was quite small and there was no increase in serum phosphorus levels. In contradistinction to mice, indomethacin treatment in children did not affect serum phosphorus or its urinary phosphate excretion. It is possible that concomitant treatment with calcitriol and phosphorus will have minimized our ability to demonstrate a significant effect of indomethacin on TmP/GFR. In our previous study, Hyp mice were calcitriol and phosphorus naïve. Recent evidence has shown that calcitriol increases FGF-23 production and thus could minimize the effect of indomethacin because of higher FGF-23 levels (18). In addition, there was a significant drop out rate in our study that could have affected the overall results. Finally, our study design was a crossover rather than a randomized double blind placebo versus indomethacin trial. This study design was used, because of the limited number of patients, but is not ideal. The limitations cited above may have contributed to the negative results of indomethacin therapy in our patients. Further studies are needed to determine whether nonsteroidal antiinflammatory agents affect urinary phosphate excretion given the limitations of this study. In conclusion, urinary $\mathrm{PGE}_{2}$ is comparable in children with $\mathrm{HPR}$ as in controls. In addition, treatment with indomethacin in the current clinical setting does not appear to be beneficial in children with XLH as it is in Hyp mice.

\section{REFERENCES}

1. Rasmussen H, Tenehouse HS 1995 Mendelian hypophosphatemia. In: Scriver CR, Beaudet AL, Sly WS, Valle D (eds) The Metabolic Basis of Inherited Disease. New York: McGraw-Hill, pp 3717-3745

2. Holm IA, Huang X, Kunkel LM 1997 Mutational analysis of the PEX gene in patients with X-linked hypophosphatemic rickets. Am J Hum Genet 60:790-797

3. Jonsson KB, Zahradnik R, Larsson T, White KE, Sugimoto T, Imanishi Y, Yamamoto T, Hampson G, Koshiyama H, Ljunggren O, Oba K, Yang IM, Miyauchi A, Econs M, Lavigne J, Juppner H 2003 FGF 23 in oncogenic osteomalacia and X-linked hypophosphatemia. N Engl J Med 348:1656-1663

4. White KE, Jonsson KB, Carn G, Hampson G, Spector TD, Mannstadt M, LorenzDepiereux B, Miyauchi A, Yang IM, Ljunggren O, Meitinger T, Strom TM, Juppner $\mathrm{H}$, Econs MJ 2001 The autosomal dominant hypophosphatemic rickets (ADHR) gene is a secreted polypeptide over-expressed by tumors that cause phosphate wasting. J Clin Endocrinol Metab 86:497-500

5. Shimada T, Muto T, Urakawa I, Yoneya T, Yamazaki Y, Okawa K, Takeuchi Y, Fujita T, Fukumoto S, Yamashita T 2002 Mutant FGF-23 responsible for autosomal dominant hypophosphatemic rickets is resistant to proteolytic cleavage and causes hypophosphatemia in vivo. Endocrinology 143:3179-3182

6. Baum M, Loleh S, Saini N, Seikaly M, Dwarakanath V, Quigley R 2003 Correction of proximal tubule phosphate transport defect in Hyp mice in vivo and in vitro with indomethacin. Proc Natl Acad Sci USA 100:11098-11103

7. Syal A, Schiavi S, Chakravarty S, Dwarakanath V, Quigley R, Baum M 2006 Fibroblast growth factor-23 increases mouse PGE2 production in vivo and in vitro. Am J Physiol Renal Physiol 290:F450-F455

8. Seikaly MG, Browne RH, Baum M 1994 The effect of phosphate supplementation on linear growth in children with X-linked hypophosphatemia. Pediatrics 94:478481

9. Alon U, Hellerstein S 1994 Assessment and interpretation of tubular threshold for phosphate in infants and children. Pediatr Nephrol 8:250-251

10. Choukair MK 2000 Blood chemistries/body fluids. In: Siberry GK, Iannone R (eds) The Harriet Lane Handbook. 15th ed. St. Louis: Mosby, pp 119-130

11. Schmitt CP, Mehls O 2004 The enigma of hyperparathyroidism in hypophosphatemic rickets. Pediatr Nephrol 19:473-477

12. Seikaly M, Browne R, Baum M 1996 Nephrocalcinosis is associated with renal tubular acidosis in children with X-linked hypophosphatemia. Pediatrics 97:91-93

13. Agnoli GC, Borgatti R, Cacciari M, Garutti C, Ikonomu E, Lenzi P, Marinelli M, Stipo L 1996 Responses of the renal prostanoids to a short-term depletion of sodium or potassium in healthy women. Boll Soc Ital Biol Sper 72:109-116

14. Harris RC, Breyer MD 2001 Physiological regulation of cyclooxygenase-2 in the kidney. Am J Physiol Renal Physiol 281:F1-F11

15. Qi Z, Cai H, Morrow JD, Breyer MD 2006 Differentiation of cyclooxygenase 1- and 2-derived prostanoids in mouse kidney and aorta. Hypertension 48:323-328

16. Schlondorff D 1986 Renal prostaglandin synthesis: sites of production and specific actions of prostaglandins. Am J Med 81:1-11

17. Imbert-Teboul M, Siaume S, Morel F 1986 Sites of prostaglandin E2(PGE2) synthesis along the rabbit nephron. Mol Cell Endocrinol 45:1-10

18. Liu S, Tang W, Zhou J, Stubbs JR, Lou Q, Pi M, Quarles DL 2006 Fibroblast growth factor 23 is a counter-regulatory phosphaturic hormone for vitamin D. J Am Soc Nephrol 17:1305-1315 